\title{
The Global Geoscience Transects Project
}

\section{by J.W.H. Monger}

The Global Geoscience Transects project is a new activity of the International Lithosphere Program (ILP). It is modelled generally after the Decade of North American Geology continent-ocean transects program. However, the GGT emphasizes the continental crust, which contains $95 \%$ of the preserved record of earth history, rather than the transition between oceans and continents.

\section{Introduction}

The term transect as used by the GGT refers to a crosssection showing the composition and structure of the entire crust of the Earth and, where possible, the lower lithosphere. It incorporates and integrates all available geological, geochemical and geophysical data. Transects lie along corridors $100 \mathrm{~km}$ wide and up to a few thousand kilometers long, positioned by regional experts to cross major crustal features. Ideally, they are a type of geological strip map in the vertical plane that can be used to show how the erust represented there formed.

A major purpose of GGT is to encourage preparation of transect displays in a common format, so that crust in different parts of the world can be compared directly. The project is intended to utilize the vast amount of geological and geophysical information, collected partly for economic reasons, that already exists, mainly in national surveys. The quality and availability of these data are best known and evaluated by local experts. Thus, for the project to be viable, it must involve scientists at the "grass-roots" level, and give them the opportunity to share in a project of global scope and at the for efront of earth science research.

What is a Crustal Transect?

Geological cross-sections and the maps they commonly accompany are a necessary part of the geological analysis of any area. They are based on direct observation and current interpretation of composition, age and structure of surface rocks. The regional structural style obtained from the map is important, so that large-scale structures along trend can be projected down the plunge to define subsurface structures in the line of section. In places, surface data are supplemented directly by subsurface information from drill holes and tunnels, and, indirectly, by geophysical data, particularly in regions of interest to the petroleum industry. Typically, such geological cross-sections extend no more than a few thousand metres below the earth's surface.

In contrast to these relatively shallow and local crosssections are interpretative sections based on regional geology, which have for many years been part of tectonic syntheses of regions such as the European Alps. The intensive work on the well-exposed rocks of the Alps with their distinctive and contrasting seouences led to the early recognition that very different stratigraphic facies were superposed on thrust faults of great displacement. The magnificent serial cross-sections drawn to depths of $10 \mathrm{~km}$ by Staub (1924) led directly to the first transects: namely, cross-sections embracing much of the erust and showing the origin and probable present disposition of the major crustal elements (e.g. Fig. 1).

Deeper parts of the crust and the subcrustal lithosphere are generally investigated by geophysical techniques. Geological observations on these inacessible regions are limited to the few places where former deep crust, recognized by its metamorphic mineralogy, is exposed as the result of tectonic uplift, and where rocks from great depths are brought to the surface in volcanic necks and in diapirs. The geochemistry of magmatic rocks yields somewhat equivocal clues about the composition of deeper regions. The cost of direct access by deep drilling is too great for more than a

Figure 1: Generalized section showing the structure of the Alps (modified from E. Argand, in Collett, 1935). The section, showing the Eastern Alps overriding the western Alps, is a composite made by projecting downplunge detailed. serial crosssections; the total thickness shown approximates crustal magnitude.

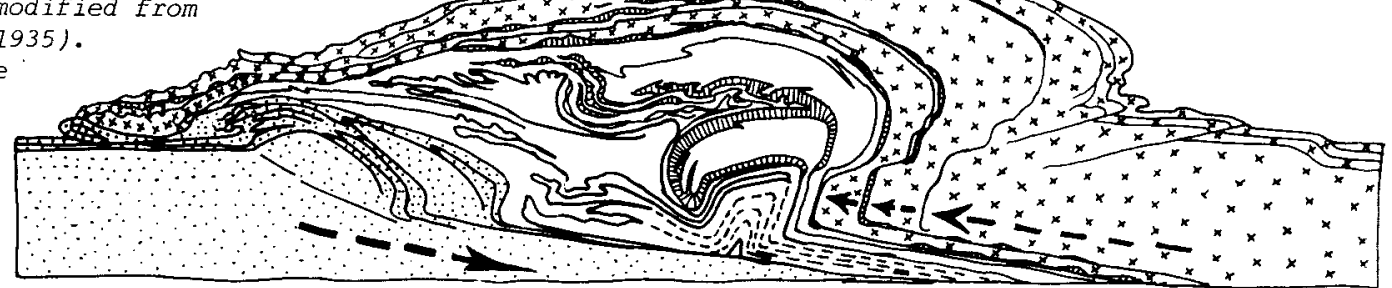




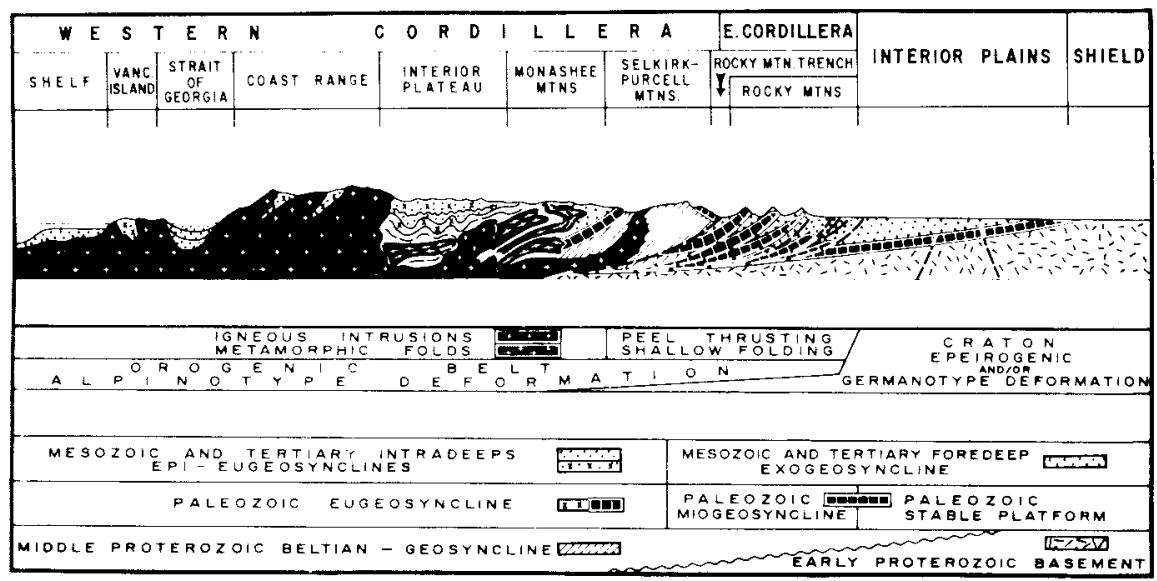

Figure 2: Synoptic cross-section of the southern Canadian Cordillera (reproduced from Bally et al., 1966, with permission of the Bulletin of Canadian Petroleum Geology).

al., 1978), and the raising of the possibility that crystalline rocks of the Appalachians form part of an enormous thrust sheet (Cook et al., 1979), have substantially modified our concepts of crustal structure.

The North American Transects Program

In 1978, the United States Geodynamics Committee initiated the continentocean transect project. This was

few deep holes globally, and with present technology these are unlikely to penetrate far into lower parts of the continental crust.

Geophysical techniques are widely applicable and relatively cheap, but gravity, seismic refraction, magnetic and heat flow studies provide very different kinds of data from geological sampling, and these may be difficult to interpret in geological terms. On the one hand, crustal sections derived from geophysics are typically simple and quantitative, but rather poorly constrained, as they renerally represent only one of a possible range of options. On the other hand, sections derived from geological studies tend to be complex, due to the widespread nature of surface sampling, and qualitative.

Ceophysies typically measures today's world, whereas geology is very much concerned with changes through time. For example, a representative seismic section through the Alps (Figure 7 of Mueller et al., 1980) shows a simple density layering, whereas a geological section (such as that in Fig. 1) shows the possible crustal disposition of rock units, based on the concept that rocks once widely distributed now are stacked vertically to make up the crust. Cross-sections of the crust in regions where there is deep geophysical information commonly exhibit a dichotomy in which the upper few kilometres show a great complexity based on geology, and in which the lower section is more simplistic with divisions based on densities.

The integration of these different geological and geophysical perspectives is perhaps the major challenge of GGT. this integration has been done in the upper crust for many vears, with considerable commercial success, by the petroleum industry. Seismic reflection images, particularly the multichannel computer-processed variety, resemble geological cross-sections in that they show the geometry of reflectors within the crust. These images may be readily related to geology where the reflector coincides with a lithological unit or structure that can be directly observed at the surface or in drill holes.

The first cross-sections of the Canadian Cordillera that compared in scope with the classic Alpine sections were drawn by petroleum explorationists (Fig. 2). Cross-sections in the petroliferous Rocky Mountain fold and thrust belt, well constrained at depth by drill-holes and seismic reflection lines, were extended westwards by the technique of balancing cross-sections into regions of granitic and highgrade metamorphic rocks.

tore recently, the COCORP program in the United States has explored the crust to great depths using sophisticated, commercially available seismic reflection techniques pioneered by the petroleum industry. The spectacular results of this program, such as the tracing of the Wind River Thrust in Wyoming to a depth of $24 \mathrm{~km}$ (Smithson, et joined shortly afterwards by the Canadian Committee on the Lithosphere and the Institute of Geology, University of Mexico, to become the North American transects program. This was designed to incorporate and integrate the considerable amount of mainly seismic reflection data from the offshore regions of North America, with existing geological and geophysical information from contiguous parts of the continent. The purpose was to explore the transition between continental and ocean crust in marginal parts of the continent.

Prior to this time, most published eross-sections fell into one of two categories: classic on-land geological profiles, and newer off-shore sections based on seismic reflection data. The two were separated by the shoreline and rarely integrated into a single profile. The project resulted in a series of cross-sections of the entire crust from the stable continental interior, through the marginal Phanerozoic

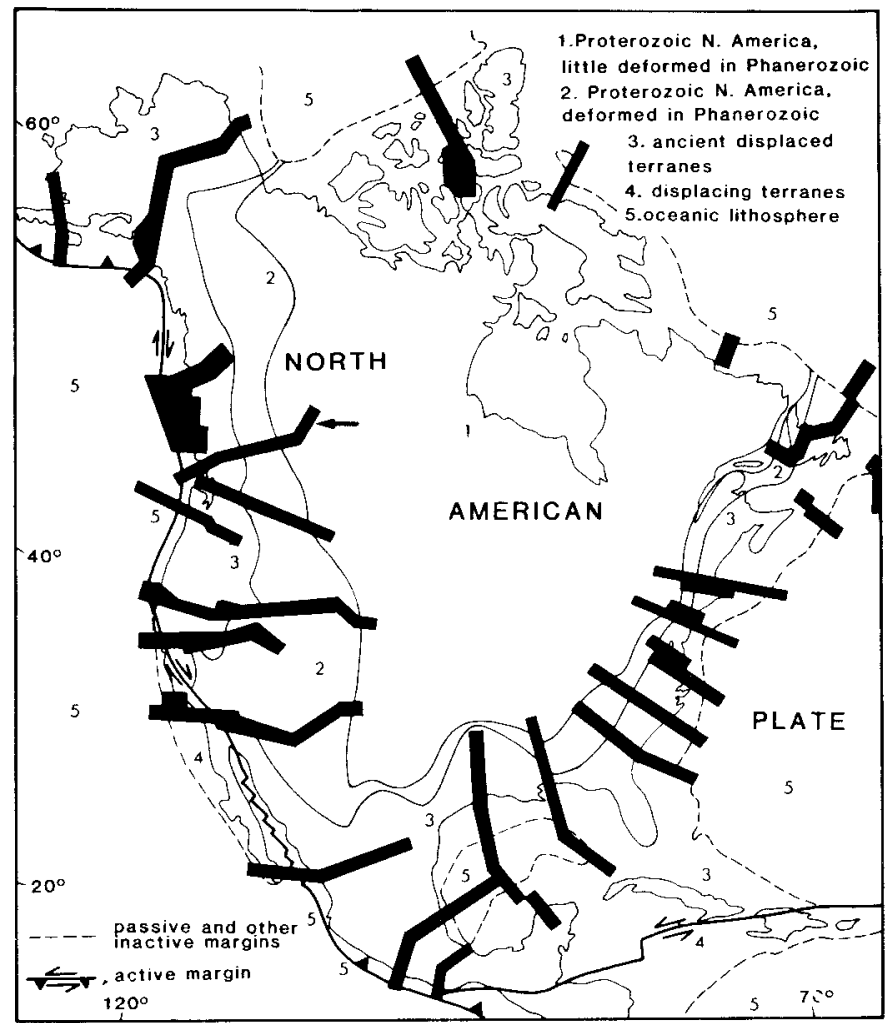

Figure 3: Location of the North Anerican continentocean transects. 
mobile belts, into the ocean basins. The transects are now being published by the Geological Society of America as a product of the Decade of North American Geology (Fig. 3). About 200 geoseientists were involved in the project, and to date $t$ welve out of twenty-six transects have been printed.

Annual workshops for transect compilers reviewed progress, discussed problems, and modified as necessary the guidelines for the format of the transect displays. The workshops were a critical and personally rewarding part of the project in that they brought compilers together, made each aware that the transect problems wrestled with in isolation were not unique, and instilled a strong sense of common purpose. For GGT to become viable, it is essential that similar workshops be held.

After much discussion, it finally became mandatory for each North American transect display to consist of the following items (Fig. 4):

1) A geological strip map $(1: 500,000$ or $1: 1,000,000)$ of a corridor $100 \mathrm{~km}$ wide containing the line of the transect, with rock units coloured according to age.

2) A geological cross-section with rock units coloured according to age, and at 1:500,000, with vertical equal to horizontal scales. These include, where available, gravity and magnetic profiles, deep seismic reflection line diagrams, velocity/depth curves and seismic refraction models, a magnetotelluric model, and ancillary data such as heat flow, hypocentres, epicentres and selected isotope geochemistry.

3) A diagram showing the distribution of stratigraphic, structural, intrusive and metamorphic relationships of rock units along the line of the transect within spacetime coordinates.

4) The transect proper, accompanied by a pamphlet giving brief deseriptions of major units, sources of data and the rationale for constructing it.

The transect proper is a crustal cross-section that integrates all of the above geological and geophysical information in an interpretation of the origin and disposition of crustal components and, thus, the origin of the crust in that region. Rock units are coloured according to the tectonic settings in which they are inferred to have formed: continental platform/shelf, slope/rise, magmatic arc, oceanic, successor and foreland basins and basins related to rifting, and generalized continental crust for old cratonic rocks. Compilers are allowed considerable latitude in making the interpretation; they can be conservative and merely show generalized lower crust, or else be creative and show composition and relationships of units making up the entire crust.

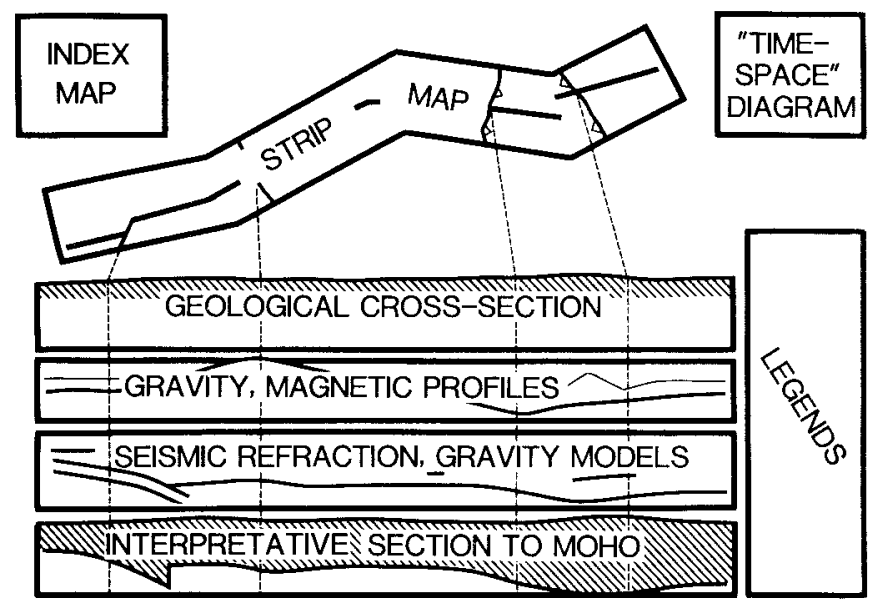

Figure 4: Lay-out of Transect $B-2$.

\section{An Example from the Canadian Cordillera}

To illustrate the problems involved, it may be useful to recall the steps followed in compiling Transect B2 across the southern Cordillera of western Canada (Monger et al,, 1985). At the time of compilation (1982), the data base included complete coverage by $1: 250,000$ scale geological maps, local detailed maps, complete gravity and sea/ airborne magnetic coverage, and a seismic refraction profile, which incorporated data of varying quality obtained in the previous 20 years. At that time the only available seismic reflection data had been collected from relatively shallow depths by oil companies in the easternmost part of the transect, and newer offshore data in the Pacific Ocean west of Vancouver Island.

The problem faced by the compiler, and generally by others with similarly limited data, was how to bridge the gap between the geological detail in the upper 5-10 km and the

Figure 5: Southern Canadian cordilleran transect (from Monger et al., 1985), showing morphostructural belts. A - Seismic refraction model; $\underline{3}$ - accreted terranes. Composite terranes I and II made up of smaller terranes that were amalgamated prior to accretion are shown as giant nappes. a.p. - Tertiary(T) to Cretaceous(K) accretionary prisms. eTv - early Tertiary volcanics.

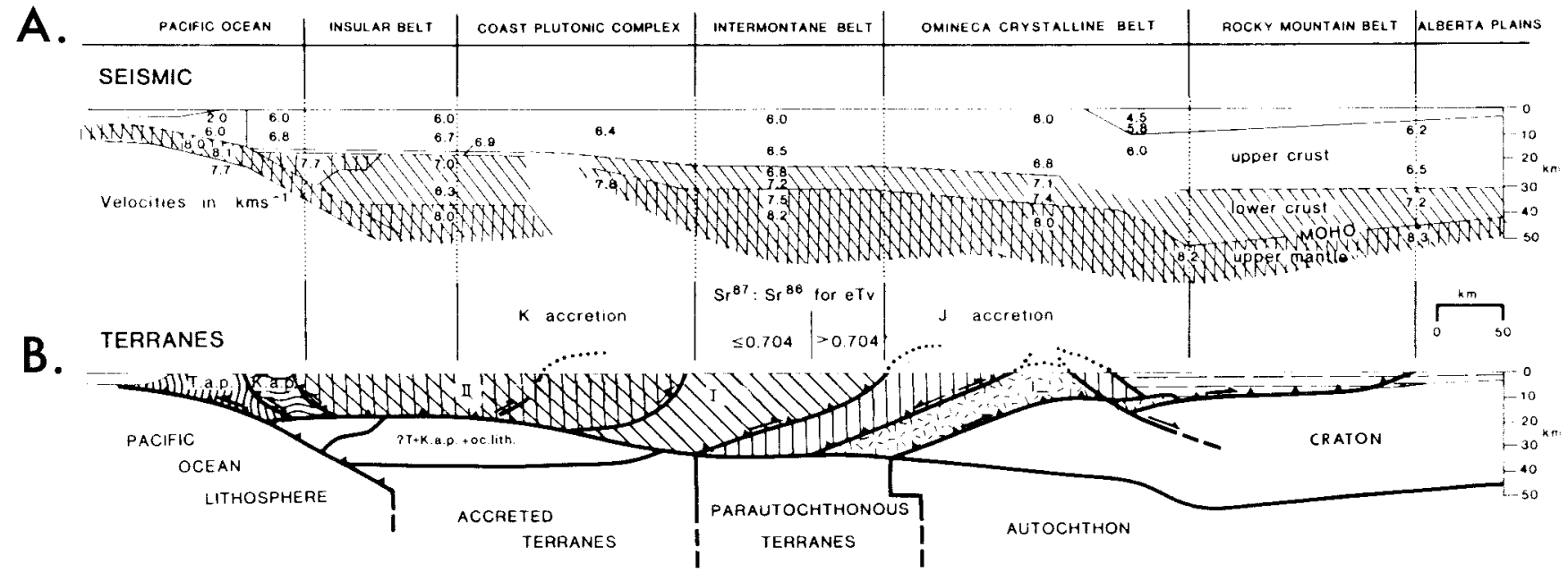




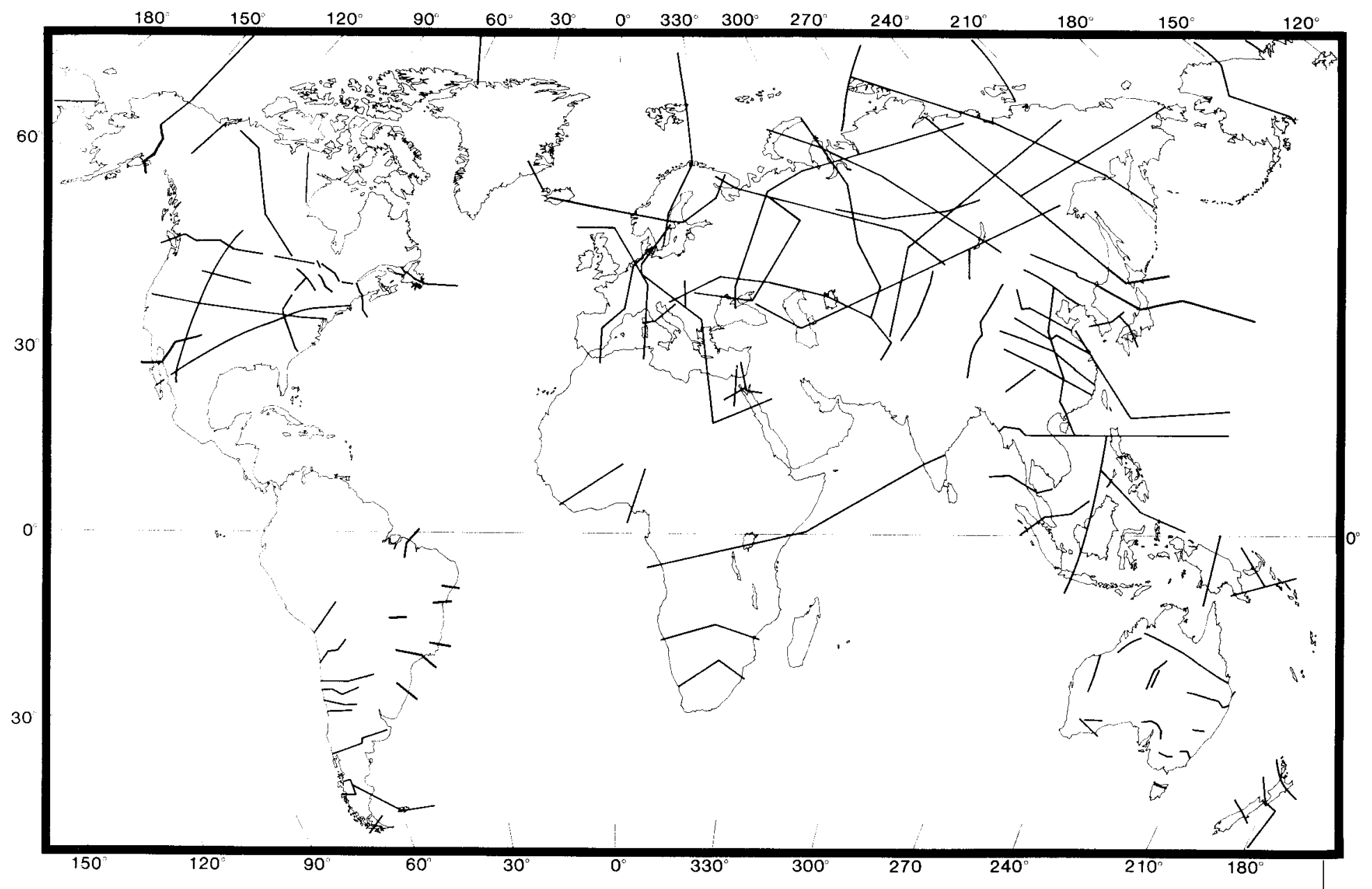

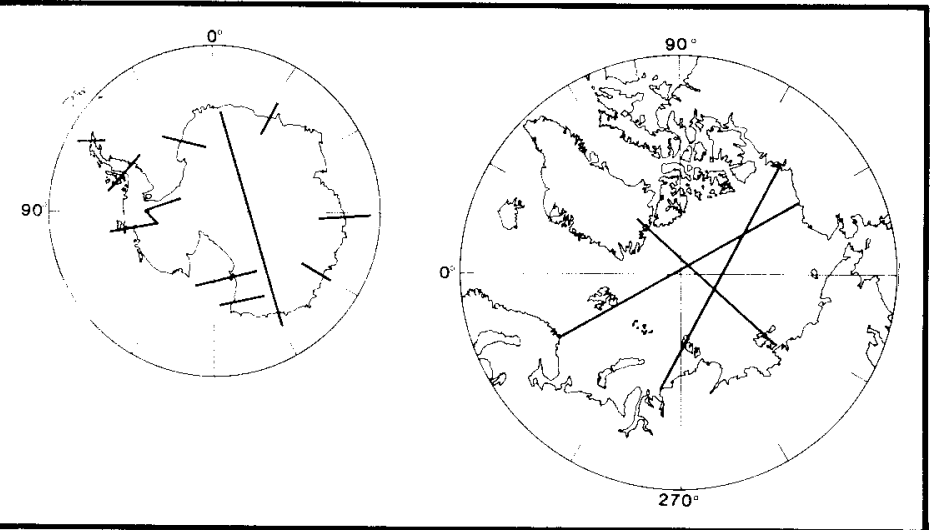

Moho. The latter varies from $45-55 \mathrm{~km}$ under the continental interior and easternmost Cordillera, to $30-35 \mathrm{~km}$ under the central Cordillera, and to $20-25 \mathrm{~km}$ under Vancouver Island (Fig. 5A). A hypothesis based on geological and geochemistry was used, according to which the present crust of the western Cordillera is largely derived from two large composite suspect terranes, each composed of rocks originating in ocean basins. The eastern of these (Composite Terrane I of Figure 5B) accreted to the ancient continental margin in Jurassic time, and the western (Composite Terrane II) in Cretaceous time (Monger et al., 1982). In the accretion process, the ensimatic terranes were thrust over or beneath North American rocks.

As seen from the refraction model of Figure $5 \mathrm{~A}$, the eastern step in the Moho coincides with the western edge of the little-deformed part of the Precambrian craton and the
Figure 6: Approximate locations of transects proposed by national/regional organizations as of October 1986.

western step is located beneath the Coast Plutonic Complex. The terranes were treated as giant nappes, on the basis of structural relationships observed at the surface; these, with magmatic additions, make up the crust of the western Cordillera. Presumably the lower crust and lower lithosphere of the accreted terranes were detached and became incorporated in subcrustal mantle.

This interpretation is no different in principle from the cross-section of Figure 1. Both are speculative because the following features could not be resolved:

- the vertical distribution of the various lithological packages through the crust, and their attitudes,

- the relative contributions to the fabric of the present crust by the various structural events seen at surface,

- the physical and chemical nature of the lower crust, and

- the volume and composition of magmatic rocks in the entire crust and their vertical distribution.

The existence of this transect, as a model to be tested, was partly responsible for the choice of location of two deep seismic reflection lines run as part of Lithoprobe, the Canadian multidisciplinary research program to investigate the nature and evolution of the lithosphere. A recent deep seismic reflection study across Vancouver Island shows Pacific Ocean crust going down beneath the outermost accreted terrane (Yorath et al., 1985). A profile in the eastern Cordillera shows reflections interpreted as late Mesozoic to earliest Tertiary compressional structures 
offset across 'Tertiary extension faults (Cook et al., in press). The new results confirm the general crustal pattern shown for those parts of transect B2, but constrain the location and orientation of rock packages and structures at depth. Eventually it is hoped to complete a deep seismic reflection profile across the entire southern Cordillera. The transect will then be redrawn, possibly as a contribution to GGT.

Two lessons are to be learned from this experience. First, given reasonable control of the surface geology and a concept of its evolution, transects can be drawn with limited geophysical data, and they can provide models to be tested by further geophysical work. Second, the approach to the problem, in particular the scale of lithological units displayed on the transect, breaks down many of the barriers between geologists and geophysicists; both are working in units of comparable scale.

\section{Current Transect Programs Elsewhere}

Other regions and nations have proposed and implemented similar programs. For example, Australia has produced profiles of orogenic belts that are similar in many ways to the North American transects (Duff et al., 1985). Many countries are now actively promoting data collecting along transect lines, rather than just using existing material as in the North American project. The European Geotraverse is a $4,000 \mathrm{~km}$ long crustal transect extending from the Precambrian Fennoscandian Shield in the north, across the Variscan realm, to the Alpine-Mediterranean region in the south (Mueller and Banda, 1983). The Soviet Union has an ambitious and exciting program of long seismic lines that are linked to, and presumably controlled by, super-deep boreholes (Kozlovsky and Yanshin, 1984). The working group on Studies in East Asian Tectonies and Resources (SEATAR) is preparing transects using extensive marine seismic lines. Encouraging responses have been received from these sources on the possibility of final publication in GGT format.

\section{The Global Geoscience Transect Project}

The GGT project was conceived in August 1985 in Tokyo by the Inter-Union Commission on the Lithosphere (ICL), which runs the ILP. Letters announcing the project were sent out to ILP National Committees and drew a widespread and favourable response. At the request of ICL, Muawia Barazangi of Cornell University prepared a global map of over 150 possible transect lines (part of which was reproduced in the March 1986 issue of Episodes). Locations of these transects were determined by reference to major geological structures and to previously implemented and proposed transects. They are designed to emphasize continental regions, though some marginal seas and island arcs are also included.

This year, 1986, has been devoted to launching GGT, and the most critical task at this time is to encourage scientists to start drawing transects. Initially, guidelines developed for the North American transects will be followed, although these will surely be modified as the project progresses and new problems are encountered.

In August 1986, ICL met in conjunction with the Fourth Circum-Pacific Energy and Mineral Resources Conference in Singapore. Representatives of several ILP National Committees brought proposed transect lines to this meeting. These lines, and others proposed by interested individuals and organizations that have agreed to coordinate their efforts with GGT, are shown in Figure 6. This map draws attention to regions where few transects have been proposed, partly because they cross international boundaries. Efforts are now being made to encourage scientists in these regions to propose transect lines that link up with those in adjacent regions.
At the Singapore meeting, ICL established a new Coordinating Committee on Global Transects (CC-7), which will be made up of about 10 regional coordinators, plus the writer as chairman. The functions of $\mathrm{CC}-7$ are to encourage compilation of transects within and between interested countries, to ensure that data and interpretation are presented uniformly so as to permit direct comparison of erust in different parts of the world, and ultimately to edit the transects for publication. Following the Singapore meeting, requests for numeric transect location data (to locate transects accurately on maps of various projections), and brief descriptions were sent out to ILP National Committees, various international groups, and interested individuals. This material will be compiled as a GGT catalogue that will provide an accurate overview of the entire project.

A key part of GGT is the direct and personal exchange of information and ideas and discussion of problems by the scientists making transect compilations. New problems will certainly arise that were not addressed in the North American program, which was concerned largely with Phanerozoic rocks of the continental margins. For example, how are Precambrian rocks in extensive platform areas with it Phanerozoic cover to be treated, or what tectonic environments are to be chosen for older Precambrian terranes? These problems can only be resolved after scientists have wrestled with them and discussed their findings with others working on similar problems. For GGT to be viable and truly "global" as many scientists as possible who are compiling transects must attend project workshops and contribute directly.

Accordingly, workshops are being organized by ILP National Committees. One will be held in Bogota, Colombia, April, 1987, and another in Irkutsk, Soviet Union, September, 1987, and transect compilers from neighbouring countries will be invited to both. CC-7 will meet at the General Assembly of the International Union of Geodesy and Geophysics to be held during August 1987 in Vancouver, Canada, and a small workshop will also be held there. Regional meetings are planned for the Latin American Geological Congress in Brazil and, tentatively, for African and Middle Eastern countries in 1988. GGT workshops, symposia and poster sessions with displays of preliminary drafts of transects will be organized for the 28th International Geological Congress during 1989 in Washington, U.S.A.

The digitization of transect data for GGT is being explored with ILP Coordinating Committee 5 , concerned with data centres and data exchange. $W$. Hinze of Purdue University is attempting to digitize one of the existing North American transects. Digitization of transects will permit rapid and accurate testing of the feasibility of transect crustal models; for example, is the crustal section as drawn compatible with the observed gravity profile? Digitization will allow rapid incorporation of new material and modification of earlier line work, and will speed up editing and publishing. All of this lies in the future. At this time the essential task is to start compiling:

\section{Conclusion}

Data on the nature and composition of the earth's crust and lower mantle are rapidly being collected by many countries. The Global Geoscience Transects project encourages all countries to use this information in a systematic manner and present it in such a way that the crust in all parts of the world can be directly compared.

We appear to be at the beginning of a new approach to an understanding of our planet: namely, the systematic mapping in three dimensions of major features of the crust of the continents. The situation today is perhaps analogous to that of the ocean basins in the early 1950s. At that time, sophisticated tools to explore the ocean basins were becoming widely available, largely as the result of instrumentation developed during the second world war. 
Today, we have newly developed geophysical techniques that make exploration of the deep crust more feasible than ever before. Discoveries were made in the ocean basins, such as magnetic stripes and transform faults, whose interpretations profoundly influenced the whole of geological science.

It is not possible to forecast the outcome of any scientific endeavor, but discoveries of at least comparable magnitude may well await us. Unlike the international waters of the ocean basins, which are freely accessible to all countries, global studies of the continental erust will require the cooperation of all countries and participation by their geoscientists. The enthusiastic response by many countries to GGT suggest that it is the ideal vehicle for encouraging this new international scientific endeavour.

Acknowledgements: Transect location data for Figure 6 were supplied by the following: Africa/Middle East: S. Riad (Egypt), B. Rumvegeri (Zaire); Antaretic: I.W.D. Dalziel, Scientific Committee for Antaretic Research; Arctic: Aretic Subcommittee of ICL; Australia: R. Rutland, National Committee for ILP; China: National Committee for ILP; India: H.K. Gupta; Japan: $\mathrm{K}$. Tamaki, National Committee for ILP; New Zealand: F. Davey; North America: Lithoprobe Steering Committee, Trans-Alaska Lithosphere Investigation, P.F. Hoffman (Canada), and K.A. Howard, W.R. Van Schmus, D.B. Stewart (U.S.A.); South America: Argentinian U. Cordani (Brazil); Southeast Asia: J.R. Curray (U.S.A.) Studies in East Asian tectonies and resources; Soviet Union: Y.A. Kozlovsky, A. Yanshin, U.S.S.R. National Committee for ILP; Western Europe: European Geotraverse, P. Giese (F.R.G.), M. Von Knorring (Finland).

Dr. J.W.H. Monger (Geological Survey of Canada, 100 West Pender Street, Vancouver, B.C. V6B 1R8) is a graduate of the Universities of Reading, Kansas and British Columbia. $\mathrm{He}$ is Coordinator of the Global Geoseience Transects project and Chairman of $\mathrm{CC}-7$, now being established. Since 1965 he has been with the GSC, involved with regional mapping and tectonies of the Canadian Cordillera. National Committee, Brazilian Geodynamies Commission,

Duff, B.A., Ward, P., Crook, K.A.W. and Rickard, M.J., 1985. Tasman orogen profile 5 Wagga Wagga - Batemans Bay, New South Wales. Sydney, N.S.W.: Dept. of Mineral Resources. Map.

Kozlovsky, Y.A. and Yanshin, A.L., 1984. Soviet Geology: achievements and prospects. Episodes, v. 7, no. 1, p. 3-8.

Monger, J.w.H., Price, R.A. and Tempelman-Kluit, D.J., 1982. Tectonic accretion and the origin of the two major metamorphic and plutonic welts in the Canadian Cordillera. Geology, v. 10, no. 2, p. 70-75.

Monger, J.w.H., Clowes, R.M., Price, R.A., Simony, P.S., Riddihough, R.P and Woodsworth, G.J., 1985. B-2 Juan de Fuca plate to Alberta Plains. Geological Society of America Centennial Continent/Ocean Transect, v. 7, 21p.

Mueller, S., Ansorge, J., Egloff, R. and Kissling, E., 1980. A crustal cross section along the Swiss Geotraverse from the Rhinegraben to the Po Plain. Ecologae Geologicae Helveticiae, v. 73 , no. 2, p. 463-488.

Mueller, S. and Banda, E., 1983. European Geotraverse Project. Terra Cognita, v. 3, no. 4, p. 291-294.

Smithson, S.B., Brewer, J., Kaufman, S., Oliver, J. and Hurich, C., 1978. Nature of the Wind River thrust, Wyoming, from COCORP deep-reflection data and from gravity data. Geology, v. 6, no. 11, p. 648-652.

Staub, R., 1924. Der Bau der Alpen. Beitrage zur Geologischen Karte der Schweiz, Geologischen Kommission der Schweiz, Bern, 272p.

Yorath, C.J., Green, A.G., Clowes, R.M., Sutherland Brown, A., Brandon, M.T., Kanasewich, E.R., Hyndman, R.D. and Spencer, C., 1985. Lithoprobe, southern Vancouver Island: seismic reflection sees through Wrangellia to the Juan de Fuca plate. Geology, v. 13, no. 11, p. 759-762.

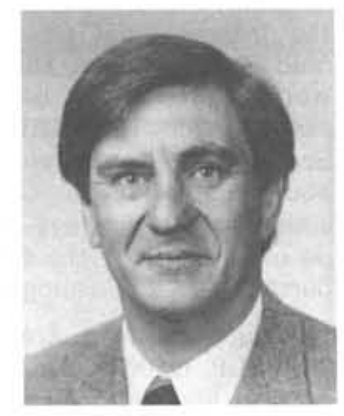

\section{References}

Bally, A.w. Gordy, P.L. and Stewart, G.A., 1966. Structure, seismic data, and orogenic evolution of the southern Canadian Rocky Mountains. Bulletin of Canadian Petroleum Geology, v. 14, no. 3, p. 337-381.

Collett, L.W., 1935. The structure of the Alps. E. Arnold \& Co., London, 2nd edition, 304p.

Cook, F.A., Albaugh, D.S., Brown, L.D., Kaufman, S., Oliver, J.E. and Hatcher, R.D. Jr., 1979. Thin-skinned tectonics in the crystalline southern Appalachians; COCORP seismic-reflection profiling of the Blue Ridge and Piedmont. Geology, v. 7, no. 12, p. 563-567.

Cook, F.A., Green, A.G., Simony, P.S., Price, R.A., Parrish, R., Milkereit, B., Gordy, P.L., Brown, R.L., Coflin, K.C. and Patenaude, C., in press. Lithoprobe southern Canadian Cordilleran transect: Rocky Mountain thrust belt to Valhalla gneiss complex. Geophysical Journal of the Royal Astronomical Society.

\section{JUST RELEASED}

IUGS PUBLICATION NO.20

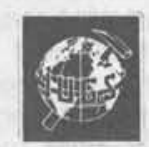

Carboniferous of the World

Volume 2

Australia, Indian Subcontinent, South Africa,

South America and North Africa

Edited by

C. Martinez Diaz, R.H. Wagner,

C.F. Winkler and L.F. Granados

Published in 1986 by Instituto Geologico y Minero de Espana and Empresa Nacional Adaro de Investigaciones Mineras, S.A., Madrid.

449 pages, 37 plates. Price \$US 50.00 (surface mail).

Available from IUGS, Room 177, 601 Booth Street, Ottawa, Ontario KIA OE8, Canada.

(Copies may also be ordered from ENADIMSA, Serrano 116 , Madrid 6 , Spain for US $\$ 45$ plus $\$ 5.00$ postage and handling.) 